\title{
SYNTHESIS, CHARACTERIZATION AND ANTIBACTERIAL ACTIVITY OF SOME NEW TRANSITION METAL COMPLEXES WITH CIPROFLOXACIN-IMINE
}

\author{
S.A. Sadeek ${ }^{1 *}$, M.S. El-Attar ${ }^{1,2}$ and S.M. Abd El-Hamid ${ }^{3}$ \\ ${ }^{1}$ Department of Chemistry, Faculty of Science, Zagazig University, Zagazig, Egypt \\ ${ }^{2}$ Medical Chemistry Dept., Preparatory Year Deanship, Jazan University, Saudi Arabia \\ ${ }^{3}$ Drinking water and sanitation company, Mansoura, Egypt
}

(Received November 25, 2014; revised May 26, 2015)

\begin{abstract}
Some new transition metal complexes of ciprofloxacin-imine derived from ciprofloxacin and ophenylenediamine were synthesized and characterized on the basis of melting point, magnetic moment, conductance measurements, elemental analysis, infrared, UV/Vis, nuclear magnetic resonance spectroscopy, mass spectra as well as thermal analyses. The data indicate that the ligand acts as tetradentate chelate bound to the metal ions through the deprotonated carboxylate and the azomethine group. The ligand as well as their metal complexes was also evaluated for their antibacterial activity against several bacterial strains such as Staphylococcus aureus, Bacillus subtilis, Escherichia coli and Pseudomonas aeruginosa and also, fungicidal activity aganist Candida albicans and Aspergillus fumigatus were tested. It was found that the metal complexes are more antibacterial as compared to uncomplexes ligand and no antifungal activity observed for ligand and their complexes. Also, this study showed that the ciprofloxacin-imine is more antibacterial as compared to ciprofloxacin alone.
\end{abstract}

KEY WORDS: Shiff base, Metal complexes, TG, IR, Mass spectra

\section{INTRODUCTION}

Schiff bases are some of the most widely used organic compounds. They are used as pigments, dyes, catalysts, intermediates in organic synthesis, and as polymer stabilizers [1]. Schiff bases have also been shown to exhibit a broad range of biological activities including antifungal, antibacterial, antimalarial, antiproliferative, anti-inflammatory, antiviral and antipyretic properties [1, 2] and also used in the design and development of anticancer chemotherapeutic agents [3]. Imine or azomethine groups are present in various natural, natural-derived, and non natural compounds. The imine group present in such compounds has been shown to be critical to their biological activities [4-6].

Schiff base ligands are able to coordinate to many different metals and stabilized in various oxidation states [7]. The Schiff bases complexes have been used in catalytic reactions and as models for biological systems [8,9]. Metal complexes play an essential role in agriculture, pharmaceutical and industrial chemistry $[10,11]$. Also aromatic Schiff bases or their metal complexes catalyze reactions on oxygenation, hydrolysis, electro-reduction and decomposition [12-14]. Earlier work has shown that some drugs studied increased activity when administrated as metal chelates rather than as organic compounds $[15,16]$ and that the coordination possibility of o-phenylenediamine has been improved by condensation with a variety of carbonyl compounds. Tetradentate Schiff bases with a $\mathrm{N}_{2} \mathrm{O}_{2}$ donor atom set are well known to coordinate with various metal ions, and this has attracted many authors [17, 18].

Some $\mathrm{Co}(\mathrm{II}), \mathrm{Cu}(\mathrm{II})$ and $\mathrm{Fe}(\mathrm{II})$ Schiff base chelate complexes show catalytic activity in oxygenation of alkene and increase the rate of hydrolysis more than simple salt $[10,13]$. Some metal complexes of a polymer bound Schiff base show catalytic activity on decomposition of hydrogen peroxide and oxidation of ascorbic acid [14]. The work reported herein is focused on the synthesis, spectroscopic and characterization of four new metal complexes [Cr(CIP-o-phdn $\left.)\left(\mathrm{H}_{2} \mathrm{O}\right)_{2}\right]\left(\mathrm{CH}_{3} \mathrm{COO}\right)_{3} \cdot 10 \mathrm{H}_{2} \mathrm{O}$, [Mn(CIP-o-phdn $\left.)\left(\mathrm{H}_{2} \mathrm{O}\right)_{2}\right] \mathrm{SO}_{4} \cdot 10 \mathrm{H}_{2} \mathrm{O}$, [Fe(CIP-o-

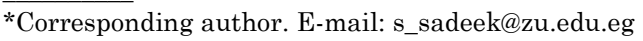


phdn $\left.)\left(\mathrm{H}_{2} \mathrm{O}\right)_{2}\right]\left(\mathrm{NO}_{3}\right)_{3} .8 \mathrm{H}_{2} \mathrm{O}$ and $\left[\mathrm{Co}(\mathrm{CIP}-\mathrm{o}-\mathrm{phdn})\left(\mathrm{H}_{2} \mathrm{O}\right)_{2}\right] \mathrm{Cl}_{2} .7 \mathrm{H}_{2} \mathrm{O}$ formed upon the reaction of $\mathrm{Cr}\left(\mathrm{CH}_{3} \mathrm{COO}\right)_{3}, \mathrm{MnSO}_{4} \cdot 6 \mathrm{H}_{2} \mathrm{O}, \mathrm{Fe}\left(\mathrm{NO}_{3}\right)_{3} \cdot 9 \mathrm{H}_{2} \mathrm{O}$ and $\mathrm{CoCl}_{2} \cdot 6 \mathrm{H}_{2} \mathrm{O}$ with new ciprofloxacin-imine (CIP-o-phdn) in the presence of acetone as a solvent and also, to study the effect of condensation of o-phenylenediamine with ciprofloxacin to produce new compound CIP-o-phdn on the antibacterial activity compared with free ciprofloxacin. The solid reaction products were characterized by melting point, molar conductivities, magnetic properties, elemental analyses, infrared spectra, $\mathrm{H}^{1}$ NMR, mass spectra, UV spectra as well as thermal analyses. The antibacterial activity of the investigated complexes, metal salts and CIP-o-phdn was tested against two Gram-positive Staphylococcus aureus, Bacillus subtilis and two Gram-negative bacterial species Escherichia coli, Pseudomonas aeruginosa and antifungal screening was studied against two species Candida albicans and Aspergillus fumigatus.

\section{EXPERIMENTAL}

\section{Chemicals}

All chemicals used for the preparation of the complexes were of analytical reagent grade, commercially available from different sources and used without further purification. Ciprofloxacin hydrochloride used in this study was purchased from the Egyptian International Pharmaceutical Industrial Company (EIPICO). o-Phenylenediamine, glacial acetic acid, acetone, ethanol, $\mathrm{NaOH}, \mathrm{FeCl}_{3} \cdot 6 \mathrm{H}_{2} \mathrm{O}, \mathrm{BaCl}_{2}, \mathrm{AgNO}_{3}, \mathrm{FeSO}_{4}$ and $\mathrm{K}_{2} \mathrm{CrO}_{4}$ were purchased from Fluka Chemical Co. $\mathrm{CoCl}_{2} \cdot 6 \mathrm{H}_{2} \mathrm{O}, \mathrm{Cr}\left(\mathrm{CH}_{3} \mathrm{COO}\right)_{3}, \mathrm{MnSO}_{4} \cdot 6 \mathrm{H}_{2} \mathrm{O}$ and $\mathrm{Fe}\left(\mathrm{NO}_{3}\right)_{3} \cdot 9 \mathrm{H}_{2} \mathrm{O}$ from Aldrich Chemical Co.

\section{Synthesis of ligand CIP-o-phdn $\left(\mathrm{C}_{40} \mathrm{H}_{42} \mathrm{~N}_{8} \mathrm{O}_{4} \mathrm{~F}_{2} \mathrm{Cl}_{2}\right)$}

An ethanolic solution of ciprofloxacin $(2 \mathrm{mmol}, 0.734 \mathrm{~g})$ with o-phenylenediamine $(1 \mathrm{mmol}$, $0.108 \mathrm{~g}$ ) was boiled under reflux in the presence of glacial acetic acid separately for $4 \mathrm{~h}$. The resulting solution was concentrated to $8 \mathrm{~mL}$ on a water bath and allowed to cool at $0{ }^{\circ} \mathrm{C}$. Yellowish white preciptate was filtered off, washed several times by ethanol and dried under vacuum over $\mathrm{CaCl}_{2}$ in a disecator. The proposed formula of the ligand $\left(\mathrm{C}_{40} \mathrm{H}_{42} \mathrm{~N}_{8} \mathrm{O}_{4} \mathrm{~F}_{2} \mathrm{Cl}_{2}, \mathrm{M}\right.$.Wt. $=807)$ is in good agreement with mass spectrum $\left(\mathrm{M}^{+}\right)$at $\mathrm{m} / \mathrm{z}=806.0(68.91 \%)$ and confirmed by IR spectral data. The ${ }^{1} \mathrm{H}$ NMR spectrum of the ligand in DMSO- $\mathrm{d}_{6}$ showed signals at $\delta 11.0$ ppm assigned to the proton of carboxylic $(\mathrm{COOH})$.

\section{Synthesis of metal complexes}

The grey solid complex $\left[\mathrm{Cr}(\mathrm{CIP}-\mathrm{o}-\mathrm{phdn})\left(\mathrm{H}_{2} \mathrm{O}\right)_{2}\right]\left(\mathrm{CH}_{3} \mathrm{COO}\right)_{3} \cdot 10 \mathrm{H}_{2} \mathrm{O}$ was prepared by adding 0.5 mmol $(0.164 \mathrm{~g})$ of chromium acetate $\mathrm{Cr}\left(\mathrm{CH}_{3} \mathrm{COO}\right)_{3}$ in $20 \mathrm{~mL}$ ethanol drop-wisely to a stirred suspended solution $0.5 \mathrm{mmol}(0.403 \mathrm{~g})$ of CIP-o-phdn and $1 \mathrm{mmol}(0.04 \mathrm{~g}) \mathrm{NaOH}$ in $50 \mathrm{~mL}$ ethanol. The reaction mixture was stirred for $15 \mathrm{~h}$ at $35{ }^{\circ} \mathrm{C}$ in water bath. The grey precipitate was filtered off and dried under vacuum over anhydrous $\mathrm{CaCl}_{2}$. The yellow, orange and green solid complexes of $\left[\mathrm{Mn}(\mathrm{CIP}-\mathrm{o}-\mathrm{phdn})\left(\mathrm{H}_{2} \mathrm{O}\right)_{2}\right] \mathrm{SO}_{4} \cdot 10 \mathrm{H}_{2} \mathrm{O}$, [ Fe(CIP-o-phdn $\left.)\left(\mathrm{H}_{2} \mathrm{O}\right)_{2}\right]\left(\mathrm{NO}_{3}\right)_{3} \cdot 8 \mathrm{H}_{2} \mathrm{O}$ and $\left[\mathrm{Co}(\mathrm{CIP}-\mathrm{O}-\mathrm{phdn})\left(\mathrm{H}_{2} \mathrm{O}\right)_{2}\right] \mathrm{Cl}_{2} .7 \mathrm{H}_{2} \mathrm{O}$ were prepared in a similar manner described above by using acetone as a solvent and using $\mathrm{MnSO}_{4} \cdot 6 \mathrm{H}_{2} \mathrm{O}, \mathrm{Fe}\left(\mathrm{NO}_{3}\right)_{3} \cdot 9 \mathrm{H}_{2} \mathrm{O}$ and $\mathrm{CoCl}_{2} \cdot 6 \mathrm{H}_{2} \mathrm{O}$, respectively, in 1:1 molar ratio. All compounds were characterized by their elemental analysis, molar conductance, magnetic moment, infrared, ${ }^{1} \mathrm{H}$ NMR, electronic, mass spectra as well as thermal analyses. Single X-ray diffraction measurements could not be obtained due to the formation of non suitable crystals. 
Elemental C, H and $\mathrm{N}$ analysis was carried out on a Perkin Elmer CHN 2400. The percentage of the metal ions were determined gravimetrically by transforming the solid products into metal oxide or sulphate, and also determined by using atomic absorption method. Spectrometer model PYE-UNICAM SP 1900 fitted with the corresponding lamp was used for this purposed. The chloride content in the complexes was determined by using Mohr's and Volhard's methods [19]. IR spectra were recorded on FTIR 460 PLUS (KBr discs) in the range from 4000-400 $\mathrm{cm}^{-1}$, ${ }_{1}^{1} \mathrm{H}$ NMR spectra were recorded on Varian Mercury VX-300 NMR Spectrometer using DMSO- $\mathrm{d}_{6}$ as solvent. TGA-DTG measurements were carried out under $\mathrm{N}_{2}$ atmosphere within the temperature range from room temperature to $800{ }^{\circ} \mathrm{C}$ using TGA-50H Shimadzu, the mass of sample was accurately weighted out in an aluminum crucible. Electronic spectra were obtained using UV-3101PC Shimadzu. The solid reflection spectra were recorded with $\mathrm{KBr}$ pellets. Mass spectra were recorded on GCMS-QP-1000EX Shimadzu (ESI-70 eV) in the range from 0-1090. Magnetic measurements were carried out on a Sherwood scientific magnetic balance using Gouy method using $\mathrm{Hg}\left[\mathrm{Co}(\mathrm{SCN})_{4}\right]$ as calibrant. Molar conductivities of the solution of the ligand and metal complexes in DMF at $1 \times 10^{-3} \mathrm{M}$ were measured on CONSORT K410. All measurements were carried out at ambient temperature with freshly prepared solution.

\section{Antimicrobial investigation}

Antibacterial activity of the ligand and its metal complexes was investigated by a previously reported modified method of Beecher and Wong [20] against different bacterial species, such as Staphylococcus aureus, Bacillus subtilis, Escherichia coli and Pseudomonas aeruginosa and antifungal screening was studied against two species, Candida albicans and Aspergillus fumigatus. The tested microorganisms isolates were isolated from Egyptian soil and identified according to the standard mycological and bacteriological keys for identification of fungi and bacteria as stock cultures in the microbiology laboratory, Faculty of Science, Zagazig University. The nutrient agar medium for antibacterial was $(0.5 \%$ peptone, $0.1 \%$ beef extract, $0.2 \%$ yeast extract, $0.5 \% \mathrm{NaCl}$ and $1.5 \%$ Agar-Agar) and CZAPEKS Dox medium for antifungal (3\% sucrose, $0.3 \% \mathrm{NaNO}_{3}, 0.1 \% \mathrm{~K}_{2} \mathrm{HPO}_{4}, 0.05 \% \mathrm{KCl}, 0.001 \% \mathrm{FeSO}_{4}, 2 \%$ AgarAgar) was prepared [21] and then cooled to $47{ }^{\circ} \mathrm{C}$ and seeded with tested microorganisms. Sterile water agar layer was poured then solidified. After solidification $5 \mathrm{~mm}$ diameter holes were punched by a sterile cork-borer. The investigated compounds, ligand, metal salts and their complexes, were introduced in Petri-dishes (only $0.1 \mathrm{~mL}$ ) after dissolving in DMF at $1.0 \times 10^{-3}$ $\mathrm{M}$. These culture plates were then incubated at $37{ }^{\circ} \mathrm{C}$ for $20 \mathrm{~h}$ for bacteria and for seven days at $30{ }^{\circ} \mathrm{C}$ for fungi. The activity was determined by measuring the diameter of the inhibition zone (in $\mathrm{mm}$ ). Growth inhibition was calculated with reference to the positive control, i.e., (ampicilin, amoxycillin and cefaloxin).

\section{RESULTS AND DISCUSSION}

The complexes of CIP-o-phdn with Cr(III), Mn(II), Fe(III) and Co(II) were synthesized as solids of a color characteristics of the metal ion. Table 1 summarizes the carbon, hydrogen, nitrogen, halogen, sulfur and metal percentages, melting points, molar conductivities and magnetic properties of the isolated solid complexes. The results obtained indicated that all of the isolated complexes are formed from the reaction of the metal salt with CIP-o-phdn in 1:1 molar ratio for all the metals. All of the complexes reported here in are hydrates with various degrees of hydration and air stable solids at room temperature. The structures of the complexes suggested from the elemental analysis agree quite well with their proposed formulae. The found values of quantitative analysis agree quite well with the calculated percentage of $\mathrm{C}, \mathrm{H}, \mathrm{N}, \mathrm{Cl}$ and $\mathrm{S}$. The 
metal content is in a well agreement with each other and proves the molecular formulae of the prepared complexes. The molar conductance values of CIP-o-phdn and their metal complexes

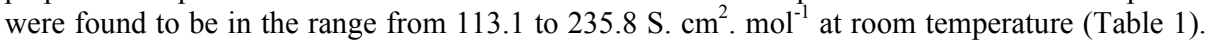
Conductance data showed that the metal complexes are electrolyte compared with ciprofloxacin Schiff base alone. The magnetic moments (as B.M.) of the complexes were measured at room temperature. The $\mathrm{Cr}(\mathrm{III}), \mathrm{Mn}(\mathrm{II}), \mathrm{Fe}(\mathrm{III})$ and $\mathrm{Co}(\mathrm{II})$ complexes are found in paramagnetism with measured magnetic moment values at 3.81, 5.62, 5.81 and 5.10 B.M., respectively. The biological activities of Schiff base and their metal chelates were studied against some selected Gram-positive and Gram-negative bacteria and two species fungi.

For the isolated complexes of $\mathrm{Cr}(\mathrm{III}), \mathrm{Mn}(\mathrm{II}), \mathrm{Fe}(\mathrm{III})$ and $\mathrm{Co}(\mathrm{II})$ in order to verify that the acetate, sulfate, nitrate and chloride groups are ionic and not coordinate, the complexes solution were tested with an aqueous solutions of ferric chloride, barium chloride, ferrous sulfate and silver nitrate a red brown, white precipitate, black-ring and white precipitate were formed. This indicate that acetate, sulfate, nitrate and chloride groups are found as counter ions (outside the complexes sphere) [22] which also in good agreement with the results of molar conductance.

Table 1. Elemental analysis and physico-analytical data for CIP-o-phdn and its metal complexes.

\begin{tabular}{|c|c|c|c|c|c|c|c|c|c|c|c|}
\hline \multirow{2}{*}{$\begin{array}{l}\text { Compounds } \\
\text { M.Wt. (M.F.) }\end{array}$} & \multirow{2}{*}{$\begin{array}{l}\text { Yield } \\
\%\end{array}$} & \multirow{2}{*}{$\underset{{ }^{\circ} \mathrm{Cp}}{\mathrm{Mp}}$} & \multirow{2}{*}{ Color } & \multicolumn{6}{|c|}{ Found (calcd.) (\%) } & \multirow{2}{*}{$\begin{array}{c}\mu_{\text {eff }} \\
\text { (B.M.) }\end{array}$} & \multirow{2}{*}{$\begin{array}{c}\Lambda \\
\mathrm{S} \mathrm{cm}^{2} \\
\mathrm{~mol}^{-1} \\
\end{array}$} \\
\hline & & & & $\mathrm{C}$ & $\mathrm{H}$ & $\mathrm{N}$ & M & $\mathrm{Cl}$ & $\mathrm{S}$ & & \\
\hline $\begin{array}{c}\text { (CIP-o-phdn) } \\
807\left(\mathrm{C}_{40} \mathrm{H}_{42} \mathrm{~N}_{8} \mathrm{O}_{4} \mathrm{~F}_{2} \mathrm{Cl}_{2}\right)\end{array}$ & 80.0 & 308 & $\begin{array}{c}\text { Yellowish } \\
\text { white }\end{array}$ & $\begin{array}{c}(59.48) \\
59.47\end{array}$ & $\begin{array}{c}(5.20) \\
5.17\end{array}$ & $\begin{array}{c}(13.88) \\
13.87\end{array}$ & - & $\begin{array}{c}(8.80) \\
8.79\end{array}$ & - & $\begin{array}{l}\text { Diama } \\
\text { gnetic }\end{array}$ & 113.1 \\
\hline $\begin{array}{c}\mathrm{Cr}(\mathrm{CIP}-\mathrm{O}- \\
\left.\text { phdn })\left(\mathrm{H}_{2} \mathrm{O}\right)_{2}\right]\left(\mathrm{CH}_{3} \mathrm{COO}\right)_{3} \\
10 \mathrm{H}_{2} \mathrm{O} \\
1179\left(\mathrm{CrC}_{46} \mathrm{H}_{73} \mathrm{~N}_{8} \mathrm{O}_{22} \mathrm{~F}_{2}\right) \\
\end{array}$ & 68.45 & 270 & Grey & $\begin{array}{c}(46.82) \\
46.80\end{array}$ & $\begin{array}{c}(6.19) \\
6.15\end{array}$ & $\begin{array}{c}(9.50) \\
9.46\end{array}$ & $\begin{array}{c}(4.41) \\
4.41\end{array}$ & - & - & 3.81 & 196.0 \\
\hline $\begin{array}{c}{[\mathrm{Mn}(\mathrm{CIP}-\mathrm{o}-} \\
\left.\text { phdn })\left(\mathrm{H}_{2} \mathrm{O}\right)_{2}\right] \mathrm{SO}_{4} \cdot 10 \mathrm{H}_{2} \mathrm{O} \\
1101 \\
\left(\mathrm{MnC}_{40} \mathrm{H}_{64} \mathrm{~N}_{8} \mathrm{O}_{20} \mathrm{~F}_{2} \mathrm{~S}\right) \\
\end{array}$ & 73.30 & 294 & Yellow & $\begin{array}{c}(43.50) \\
43.46\end{array}$ & $\begin{array}{c}(5.81) \\
5.75\end{array}$ & $\begin{array}{c}(10.17) \\
10.15\end{array}$ & $\begin{array}{c}(4.99) \\
4.92\end{array}$ & - & $\begin{array}{c}(2.92) \\
2.90\end{array}$ & 5.62 & 190.0 \\
\hline $\begin{array}{c}{[\mathrm{Fe}(\mathrm{CIP}-\mathrm{o}-} \\
\left.\text { phdn })\left(\mathrm{H}_{2} \mathrm{O}\right)_{2}\right]\left(\mathrm{NO}_{3}\right)_{3} .8 \mathrm{H}_{2} \\
\mathrm{O} \\
1155.8 \\
\left(\mathrm{FeC}_{40} \mathrm{H}_{60} \mathrm{~N}_{11} \mathrm{O}_{23} \mathrm{~F}_{2}\right) \\
\end{array}$ & 69.82 & $>360$ & Orange & $\begin{array}{c}(41.53) \\
41.50\end{array}$ & $\begin{array}{c}(5.19) \\
5.15\end{array}$ & $\begin{array}{c}(13.32) \\
13.29\end{array}$ & $\begin{array}{c}(4.83) \\
4.80\end{array}$ & - & - & 5.81 & 235.8 \\
\hline $\begin{array}{c}{[\mathrm{Co}(\mathrm{CIP}-\mathrm{O}-} \\
\left.\text { phdn })\left(\mathrm{H}_{2} \mathrm{O}\right)_{2}\right] \mathrm{Cl}_{2} .7 \mathrm{H}_{2} \mathrm{O} \\
1025.9 \\
\left(\mathrm{CoC}_{40} \mathrm{H}_{58} \mathrm{~N}_{8} \mathrm{O}_{13} \mathrm{~F}_{2} \mathrm{Cl}_{2}\right)\end{array}$ & 78.66 & 282 & Green & $\begin{array}{c}(46.79) \\
46.70\end{array}$ & $\begin{array}{c}(5.65) \\
5.62\end{array}$ & $\begin{array}{c}(10.92) \\
10.89\end{array}$ & $\mid \begin{array}{c}(5.74) \\
5.70\end{array}$ & $\begin{array}{c}(6.92) \\
6.90\end{array}$ & - & 5.10 & 230.8 \\
\hline
\end{tabular}

\section{IR absorption spectra}

The infrared spectra of $\left[\mathrm{Cr}(\mathrm{CIP}-\mathrm{o}-\mathrm{phdn})\left(\mathrm{H}_{2} \mathrm{O}\right)_{2}\right]\left(\mathrm{CH}_{3} \mathrm{COO}\right)_{3} \cdot 10 \mathrm{H}_{2} \mathrm{O}, \quad[\mathrm{Mn}(\mathrm{CIP}-\mathrm{o}-\mathrm{phdn})$ $\left.\left(\mathrm{H}_{2} \mathrm{O}\right)_{2}\right] \mathrm{SO}_{4} \cdot 10 \mathrm{H}_{2} \mathrm{O}$, [Fe(CIP-o-phdn $\left.)\left(\mathrm{H}_{2} \mathrm{O}\right)_{2}\right]\left(\mathrm{NO}_{3}\right)_{3} \cdot 8 \mathrm{H}_{2} \mathrm{O}, \quad\left[\mathrm{Co}(\mathrm{CIP}-\mathrm{o}-\mathrm{phdn})\left(\mathrm{H}_{2} \mathrm{O}\right)_{2}\right] \mathrm{Cl}_{2} .7 \mathrm{H}_{2} \mathrm{O}$ and CIP-o-phdn were measured as $\mathrm{KBr}$ discs. The assignments are given in Table 2. The infrared spectra of the complexes are compared with those of CIP-o-phdn in order to determine the site of coordination that may be involved in chelation. There are some guide peaks in the spectra of the ligand which are of good help for achieving this goal. These peaks are expected to be involved in chelation. The position or the intensities of these peaks are expected to be changed upon complexation. The proposed structures for all complexes is represented by Scheme 1, the four donor atoms of CIP-o-phdn coordinated to central metal ions in a plane forming tetragon with the two oxygen atoms of the two coordinated water molecules in axial 
position [18]. According to the proposed structures for the complexes under investigation, the complexes posses a two-fold axis and two plane of symmetry and hence they are $\mathrm{C}_{2 v}$ symmetry. The $\mathrm{C}_{2 v}$ complexes, [M(CIP-o-phdn $\left.)\left(\mathrm{H}_{2} \mathrm{O}\right)_{2}\right]^{\mathrm{n}+}$ are expected to display 297 vibrational fundamentals which are all monodegenerate. These are distributed between $A_{1}, A_{2}, B_{1}$ and $B_{2}$ motions; all are IR and Raman active, except for the $\mathrm{A}_{2}$ modes which are only Raman active.

Table 2. Infrared frequencies $\left(\mathrm{cm}^{-1}\right)$ and tentative assignments for (A) CIP-o-phdn; (B) [Cr(CIP-o-phdn) $\left.\left(\mathrm{H}_{2} \mathrm{O}\right)_{2}\right]\left(\mathrm{CH}_{3} \mathrm{COO}\right)_{3} \cdot 10 \mathrm{H}_{2} \mathrm{O},(\mathrm{C})\left[\mathrm{Mn}(\mathrm{CIP}-\mathrm{o}-\mathrm{phdn})\left(\mathrm{H}_{2} \mathrm{O}\right)_{2}\right] \mathrm{SO}_{4} \cdot 10 \mathrm{H}_{2} \mathrm{O}$, (D) [ Fe(CIP-o-phdn) $\left.\left(\mathrm{H}_{2} \mathrm{O}\right)_{2}\right]$ $\left(\mathrm{NO}_{3}\right)_{3} \cdot 8 \mathrm{H}_{2} \mathrm{O}$ and (E) $\left[\mathrm{Co}(\mathrm{CIP}-\mathrm{o}-\mathrm{phdn})\left(\mathrm{H}_{2} \mathrm{O}\right)_{2}\right] \mathrm{Cl}_{2} \cdot 7 \mathrm{H}_{2} \mathrm{O}$.

\begin{tabular}{|c|c|c|c|c|c|}
\hline $\mathrm{A}$ & $\mathrm{B}$ & $\mathrm{C}$ & $\mathrm{D}$ & $\mathrm{E}$ & Assignments \\
\hline $3533 w$ & $\begin{array}{l}3522 \mathrm{w} \\
3478 \mathrm{w}\end{array}$ & $3341 \mathrm{mbr}$ & $3545 \mathrm{w}$ & $3375 \mathrm{mbr}$ & $v(\mathrm{O}-\mathrm{H}) ; \mathrm{H}_{2} \mathrm{O} ; \mathrm{COOH}$ \\
\hline $\begin{array}{l}3156 w \\
3044 w\end{array}$ & $\begin{array}{l}3133 \mathrm{vw} \\
3067 \mathrm{vw} \\
3040 \mathrm{~ms}\end{array}$ & $\begin{array}{l}3067 \mathrm{vw} \\
3009 \mathrm{~m}\end{array}$ & 3044 sh & $\begin{array}{c}3089 \mathrm{vw} \\
3022 \mathrm{w}\end{array}$ & $v(\mathrm{C}-\mathrm{H}) ;$ aromatic \\
\hline $\begin{array}{c}2943 \mathrm{~s} \\
2867 \mathrm{vw} \\
2778 \mathrm{~m} \\
2712 \mathrm{~ms}\end{array}$ & $\begin{array}{l}2955 \mathrm{~m} \\
2843 \mathrm{~m} \\
2767 \mathrm{w} \\
2722 \mathrm{w} \\
2712 \mathrm{~m}\end{array}$ & $\begin{array}{c}2889 w \\
2766 w \\
2711 \mathrm{vw}\end{array}$ & $\begin{array}{l}2974 \mathrm{~m} \\
2871 \mathrm{vw} \\
2800 \mathrm{~m} \\
2758 \mathrm{w}\end{array}$ & $\begin{array}{c}2955 \mathrm{~m} \\
2822 \mathrm{vw} \\
2756 \mathrm{w} \\
2716 \mathrm{~m}\end{array}$ & $v(\mathrm{C}-\mathrm{H})$; aliphatic \\
\hline $\begin{array}{l}2650 \mathrm{~m} \\
2611 \mathrm{~m} \\
2465 \mathrm{~s}\end{array}$ & $\begin{array}{c}2644 \mathrm{~m} \\
2615 \mathrm{w} \\
2465 \mathrm{~ms}\end{array}$ & $\begin{array}{l}2658 \mathrm{vw} \\
2554 \mathrm{w}\end{array}$ & $\begin{array}{c}2689 \mathrm{vw} \\
2642 \mathrm{vw} \\
2507 \mathrm{~m}\end{array}$ & $\begin{array}{c}2650 \mathrm{~m} \\
2611 \mathrm{w} \\
2465 \mathrm{~ms}\end{array}$ & $v\left(-\mathrm{NH}_{2}^{+}\right)$ \\
\hline $1732 \mathrm{vs}$ & - & - & - & - & $v(\mathrm{C}=\mathrm{O}) ; \mathrm{COOH}$ \\
\hline- & 1620vs & $1620 \mathrm{vs}$ & $1622 \mathrm{~m}$ & $1624 \mathrm{~s}$ & $v_{\mathrm{as}}\left(\mathrm{COO}^{-}\right)$ \\
\hline $1624 \mathrm{vs}$ & $1589 \mathrm{~s}$ & $1574 \mathrm{~s}$ & $1574 \mathrm{~s}$ & $1570 \mathrm{vs}$ & $v(\mathrm{C}=\mathrm{N})$ \\
\hline 1466vs & $\begin{array}{c}1539 \mathrm{~m} \\
1494 \mathrm{~s} \\
1474 \mathrm{~s} \\
\end{array}$ & $1485 \mathrm{vs}$ & $1462 \mathrm{vs}$ & $1485 \mathrm{~s}$ & $\begin{array}{c}\text {-CH; deformations of } \\
\mathrm{CH}_{2}\end{array}$ \\
\hline $\begin{array}{l}1385 \mathrm{~m} \\
1367 \mathrm{sh} \\
\end{array}$ & $1377 \mathrm{~s}$ & $\begin{array}{c}1393 \mathrm{~s} \\
1378 \mathrm{w} \\
\end{array}$ & $\begin{array}{l}1385 \mathrm{vs} \\
1350 \mathrm{sh} \\
\end{array}$ & $1393 \mathrm{~s}$ & $\begin{array}{c}v_{\mathrm{s}}\left(\mathrm{COO}^{-}\right) \text {and } \\
v\left(\mathrm{NO}_{3}^{-}\right) \\
\end{array}$ \\
\hline $1331 \mathrm{~ms}$ & $1322 \mathrm{~m}$ & $1304 \mathrm{~ms}$ & $1300 \mathrm{~m}$ & $1308 \mathrm{~s}$ & $\delta_{\mathrm{b}}\left(-\mathrm{CH}_{2}\right)$ \\
\hline $\begin{array}{l}1261 \mathrm{vs} \\
1223 \mathrm{w} \\
1188 \mathrm{~m} \\
1156 \mathrm{~m}\end{array}$ & $\begin{array}{c}1285 \mathrm{~s} \\
1211 \mathrm{sh} \\
1172 \mathrm{vw} \\
1146 \mathrm{~ms}\end{array}$ & $\begin{array}{c}1269 \mathrm{~s} \\
1189 \mathrm{vw} \\
1144 \mathrm{w}\end{array}$ & $\begin{array}{l}1269 \mathrm{~s} \\
1184 \mathrm{~m} \\
1146 \mathrm{~m}\end{array}$ & $\begin{array}{l}1265 \mathrm{~s} \\
1184 \mathrm{~m} \\
1146 \mathrm{~m}\end{array}$ & $\begin{array}{c}v(\mathrm{C}-\mathrm{O}), \\
v(\mathrm{C}-\mathrm{N}) \text { and } \\
v(\mathrm{C}-\mathrm{C})\end{array}$ \\
\hline $\begin{array}{c}1089 \mathrm{~m} \\
1034 \mathrm{~s}\end{array}$ & $1034 \mathrm{~s}$ & $\begin{array}{l}1103 \mathrm{~m} \\
1072 \mathrm{sh} \\
1038 \mathrm{~m}\end{array}$ & $1038 \mathrm{~ms}$ & $\begin{array}{c}1107 \mathrm{~m} \\
1034 \mathrm{~s}\end{array}$ & $\begin{array}{l}\delta_{\mathrm{r}}\left(-\mathrm{CH}_{2}\right) \\
v\left(\mathrm{SO}_{4}^{-2}\right)\end{array}$ \\
\hline $\begin{array}{c}989 \mathrm{vw} \\
968 \mathrm{~m} \\
933 \mathrm{~m} \\
887 \mathrm{~ms} \\
833 \mathrm{~ms} \\
822 \mathrm{vw} \\
\end{array}$ & $\begin{array}{c}989 \mathrm{w} \\
937 \mathrm{~ms} \\
894 \mathrm{w} \\
867 \mathrm{~m} \\
833 \mathrm{~ms}\end{array}$ & $\begin{array}{l}989 \mathrm{vw} \\
941 \mathrm{~ms} \\
911 \mathrm{vw} \\
829 \mathrm{~m}\end{array}$ & $\begin{array}{c}945 \mathrm{~ms} \\
899 \mathrm{~m} \\
844 \mathrm{~m} \\
822 \mathrm{w} \\
800 \mathrm{vw}\end{array}$ & $\begin{array}{l}945 \mathrm{~s} \\
895 \mathrm{~m} \\
829 \mathrm{~m}\end{array}$ & $\begin{array}{c}\text {-CH-bend; phenyl } \\
v\left(\mathrm{NO}_{3}^{-}\right)\end{array}$ \\
\hline $\begin{array}{c}795 \mathrm{~m} \\
767 \mathrm{vw} \\
748 \mathrm{~m} \\
710 \mathrm{~m}\end{array}$ & $\begin{array}{l}783 \mathrm{~m} \\
721 \mathrm{~s}\end{array}$ & $\begin{array}{c}779 \mathrm{~m} \\
745 \mathrm{~s} \\
710 \mathrm{w}\end{array}$ & $\begin{array}{l}778 \mathrm{w} \\
752 \mathrm{~m} \\
711 \mathrm{~m}\end{array}$ & $\begin{array}{c}778 \mathrm{~m} \\
748 \mathrm{~s} \\
710 \mathrm{~m}\end{array}$ & $\delta_{\mathrm{b}}\left(\mathrm{COO}^{-}\right)$ \\
\hline $\begin{array}{c}656 \mathrm{w} \\
622 \mathrm{~m} \\
571 \mathrm{~ms} \\
486 \mathrm{~m} \\
478 \mathrm{vw} \\
436 \mathrm{~s}\end{array}$ & $\begin{array}{c}644 \mathrm{vw} \\
621 \mathrm{~ms} \\
559 \mathrm{~s} \\
494 \mathrm{~ms} \\
436 \mathrm{~m}\end{array}$ & $\begin{array}{c}625 \mathrm{~ms} \\
578 \mathrm{~m} \\
544 \mathrm{w} \\
502 \mathrm{~m} \\
478 \mathrm{w} \\
433 \mathrm{w} \\
413 \mathrm{w}\end{array}$ & $\begin{array}{c}633 \mathrm{~ms} \\
583 \mathrm{~m} \\
544 \mathrm{w} \\
505 \mathrm{~s} \\
422 \mathrm{w}\end{array}$ & $\begin{array}{l}667 \mathrm{vw} \\
629 \mathrm{~m} \\
578 \mathrm{w} \\
544 \mathrm{~m} \\
502 \mathrm{~m} \\
440 \mathrm{w}\end{array}$ & $\begin{array}{l}v(\mathrm{M}-\mathrm{N}), \mathrm{v}(\mathrm{M}-\mathrm{O}) \text { and ring } \\
\text { deformation }\end{array}$ \\
\hline
\end{tabular}

Keys: $\mathrm{s}=$ strong, $\mathrm{w}=$ weak, $\mathrm{v}=$ very, $\mathrm{m}=$ medium, $\mathrm{br}=$ broad, $\mathrm{sh}=$ shoulder, $v=$ stretching, $\delta_{b}=$ bending. 
The infrared spectrum of CIP-o-phdn shows the absence of the bands attributable to $v\left(\mathrm{NH}_{2}\right)$ group of o-phenylenediamine and $v(\mathrm{C}=\mathrm{O})$ of ciprofloxacin. Instead, newly formed very strong band at $1624 \mathrm{~cm}^{-1}$ is obtained. This suggests the complete condensation of the amino groups with keto group [23] indicating the formation of the Schiff base linkage [24]. The IR spectra of all complexes containing hydration and or coordination water molecules display bands at 3545$3341 \mathrm{~cm}^{-1}$ due to $v(\mathrm{O}-\mathrm{H})$ vibration mode of the water molecules [25] and this was confirmed by the results of thermal analysis. The stretching vibrations $v(\mathrm{C}-\mathrm{H})$ of phenyl, $-\mathrm{CH}_{2}$ and $-\mathrm{CH}_{3}$ groups in these compounds are assigned as a number of bands in the region $3156-2711 \mathrm{~cm}^{-1}$. The assignments of all the $\mathrm{C}-\mathrm{H}$ stretching vibrations agree quite well with the literature $[26,27]$.

The presence of a group of bands with different intensities in the range $2689-2465 \mathrm{~cm}^{-1}$, which assigned to vibration of the quaternized nitrogen of the piperazine group, indicates the zwitterionic form of CIP-o-phdn is involved in the coordination to the investigated metal ions [27]. The two bands observed at 1732 and $1624 \mathrm{~cm}^{-1}$ in the spectrum of the CIP-o-phdn have been assigned to the stretching vibration of carboxylic $v(\mathrm{COOH})$ and the azomethine group $v(\mathrm{C}=\mathrm{N})$, respectively [28-35]. The absent of the band at $1732 \mathrm{~cm}^{-1}$ in all complexes and the shift of the characteristic band of azomethine group to a lower value from $1624 \mathrm{~cm}^{-1}$ to $1589 \mathrm{~cm}^{-1}$ for $\mathrm{Cr}(\mathrm{III})$, at $1574 \mathrm{~cm}^{-1}$ for $\mathrm{Mn}$ (II) and $\mathrm{Fe}$ (III), at $1570 \mathrm{~cm}^{-1}$ for $\mathrm{Co}$ (II) indicated that the involvement of $\mathrm{C}=\mathrm{N}$ group and one oxygen of the carboxylate group in the interaction with metal ion forming six and five membered rings and the carboxylic group is deprotonated [36].

In the case of monodentate carboxylate ligand, the antisymmetric and symmetric $\left(\mathrm{COO}^{-}\right)$ stretches will be shifted to higher and lower frequencies, respectively, with an average $\Delta v>200$ $\mathrm{cm}^{-1}$ [37-43]. For our complexes the presence of band in the region 1624-1620 $\mathrm{cm}^{-1}$ in the IR spectra which assigned to the asymmetric stretching vibration $v_{\mathrm{as}}$ of the ligated carboxylato group and the symmetric vibration occurs in the region $1393-1377 \mathrm{~cm}^{-1}$ with different intensities [24, 44, 45] and with $\Delta v>200 \mathrm{~cm}^{-1}$ indicated that the carboxylate group reacts as monodentate through one of oxygen atoms.

The spectra of the isolated solid complexes showed a group of bands with different intensities which characteristics for $v(\mathrm{M}-\mathrm{N})$ and $(\mathrm{M}-\mathrm{O})$. The $v(\mathrm{M}-\mathrm{N})$ and $(\mathrm{M}-\mathrm{O})$ bands observed at 559 and $494 \mathrm{~cm}^{-1}$ for $\mathrm{Cr}(\mathrm{III})$, at $625,578,544$ and $502, \mathrm{~cm}^{-1}$ for $\mathrm{Mn}(\mathrm{II})$, at $633,583,544$ and $505 \mathrm{~cm}^{-1}$ for $\mathrm{Fe}(\mathrm{III})$, at $629,578,544$ and $502, \mathrm{~cm}^{-1}$ for $\mathrm{Co}(\mathrm{II})$ (Table 2) which are absent in the spectrum of CIP-o-phdn. This indicates the coordination of CIP-o-phdn through both $\mathrm{C}=\mathrm{N}$ and carboxylic groups $[25,26]$.

\section{Electronic spectra}

The application of ultraviolet spectroscopy is more universal and can be useful in structural determinations of all chelates since they all absorb in this region [46]. The formation of the metal ciprofloxacin Schiff base complexes was also confirmed by the electronic solid reflection spectra. The electronic solid reflection spectra of CIP-o-phdn along with the Cr(III), Mn(II), $\mathrm{Fe}(\mathrm{III})$ and $\mathrm{Co}(\mathrm{II})$ complexes in the wavelength interval from 200 to $800 \mathrm{~nm}$ range are shown in Figure 1. It can be seen that free ciprofloxacin Schiff base reflected at 209, 229 and $321 \mathrm{~nm}$ (Table 3). The first two bands at 209 and $229 \mathrm{~nm}$ may be attributed to $\pi-\pi^{*}$ transition and the second band observed at $321 \mathrm{~nm}$ is assigned to $n-\pi^{*}$ transitions, these transitions occur in case of unsaturated hydrocarbons which contain ketone groups or azomethine group [32]. The shift of the reflection bands to higher values (bathochromic shift) and the absent of the band at $321 \mathrm{~nm}$ in case of $\mathrm{Cr}(\mathrm{III}), \mathrm{Mn}(\mathrm{II}), \mathrm{Fe}(\mathrm{III})$ and $\mathrm{Co}$ (II) complexes and presence of new bands in the reflection spectra of complexes indicate that the formation of their metal complexes [28]. The four complexes have bands in the range from 414 to $624 \mathrm{~nm}$ which may be assigned to the ligand to metal charge-transfer and d-d transition. [28-30, 47].

The spectrum of Schiff base Cr(III) complex show two absorption bands 624 and $569 \mathrm{~nm}$ which are assigned to ${ }^{6} \mathrm{~A}_{2 \mathrm{~g}} \longrightarrow{ }^{4} \mathrm{~T}_{2 \mathrm{~g}}(\mathrm{~F})$ and ${ }^{4} \mathrm{~T}_{2 \mathrm{~g}} \longrightarrow{ }^{4} \mathrm{~T}_{1 \mathrm{~g}}(\mathrm{~F})$ transitions, respectively, in favor of octahedral geometry [48]. The reflectance spectrum of Mn(II) complex showed two identified 
Synthesis, characterization and antibacterial activity of some new transition metal complexes 265

bands at 619 and $571 \mathrm{~nm}$ which are assigned to ${ }^{6} \mathrm{~A}_{1 \mathrm{~g}} \longrightarrow{ }^{4} \mathrm{~T}_{1 \mathrm{~g}}\left({ }^{4} \mathrm{G}\right)$ and ${ }^{6} \mathrm{~A}_{1 \mathrm{~g}} \longrightarrow{ }^{4} \mathrm{~T}_{2 \mathrm{~g}}\left({ }^{4} \mathrm{G}\right)$ transitions, respectively [49]. The electronic spectrum of octahedral $\mathrm{Fe}(\mathrm{III})$ complex show one absorption band at $533 \mathrm{~nm}$ which are assigned to ${ }^{6} \mathrm{~A}_{1} \longrightarrow{ }^{4} \mathrm{~T}_{2}(\mathrm{G})$ transition [50]. The Schiff base $\mathrm{Co}(\mathrm{II})$ complex absorption spectrum show one absorption band at $623 \mathrm{~nm}$ which are assigned to ${ }^{4} \mathrm{~T}_{1 \mathrm{~g}}(\mathrm{~F})$ $\longrightarrow{ }^{4} \mathrm{~T}_{1 \mathrm{~g}}(\mathrm{P})$ transition in favor of octahedral geometry.

Finally, the results presented here, clearly indicated that the metal ions form stable solid complexes with CIP-o-phdn and monodentate ligand such as $\mathrm{H}_{2} \mathrm{O}$ where metal ions are six coordinate.
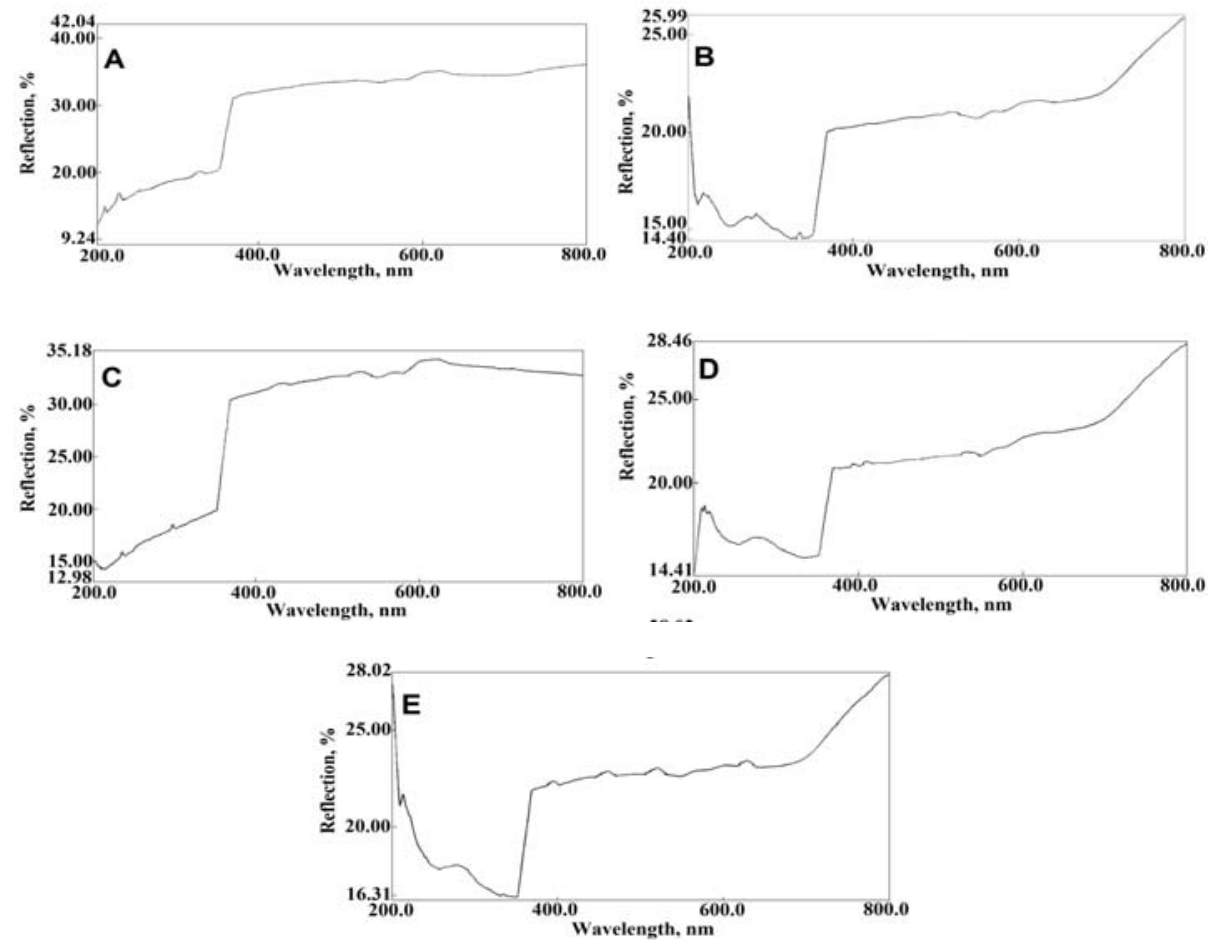

Figure 1. Electronic reflection spectra for (A) CIP-o-phdn; (B) [Cr(CIP-o-phdn) $\left.\left(\mathrm{H}_{2} \mathrm{O}\right)_{2}\right]$ $\left(\mathrm{CH}_{3} \mathrm{COO}\right)_{3} \cdot 10 \mathrm{H}_{2} \mathrm{O},(\mathrm{C})\left[\mathrm{Mn}(\mathrm{CIP}-\mathrm{o}-\mathrm{phdn})\left(\mathrm{H}_{2} \mathrm{O}\right)_{2}\right] \mathrm{SO}_{4} \cdot 10 \mathrm{H}_{2} \mathrm{O}, \quad$ (D) $\quad[\mathrm{Fe}(\mathrm{CIP}-\mathrm{o}-\mathrm{phdn})$ $\left.\left(\mathrm{H}_{2} \mathrm{O}\right)_{2}\right]\left(\mathrm{NO}_{3}\right)_{3} .8 \mathrm{H}_{2} \mathrm{O}$ and (E) $\left[\mathrm{Co}(\mathrm{CIP}-\mathrm{o}-\mathrm{phdn})\left(\mathrm{H}_{2} \mathrm{O}\right)_{2}\right] \mathrm{Cl}_{2} \cdot 7 \mathrm{H}_{2} \mathrm{O}$.

Table 3. UV-Vis. spectra of CIP-o-phdn; $\mathrm{Cr}(\mathrm{III}), \mathrm{Mn}(\mathrm{II}), \mathrm{Fe}(\mathrm{III})$ and Co(II)

\begin{tabular}{|c|c|c|c|c|c|}
\hline \multirow{2}{*}{ Assignments (nm) } & \multirow{2}{*}{$(\mathrm{CIP}-\mathrm{o}-\mathrm{phdn})$} & \multicolumn{4}{|c|}{ (CIP) Schiff base complex with } \\
\cline { 3 - 6 } & & $\mathrm{Cr}(\mathrm{III})$ & $\mathrm{Mn}(\mathrm{II})$ & $\mathrm{Fe}(\mathrm{III})$ & $\mathrm{Co}(\mathrm{II})$ \\
\hline$\pi-\pi^{*}$ transitions & 209,229 & 219 & 234 & 213,218 & 214 \\
\hline $\mathrm{n}-\pi^{*}$ transitions & 321 & $274,284,337$ & 293 & 277,398 & 280,398 \\
\hline $\begin{array}{c}\text { Ligand-metal charge } \\
\text { transfer }\end{array}$ & - & 516 & 430,520 & 414 & 456,515 \\
\hline $\mathrm{d}-\mathrm{d}$ transition & - & 569,624 & 571,619 & 533 & 623 \\
\hline
\end{tabular}




\section{${ }^{1} H$ NMR spectra}

To make sure about the proposed structure of the isolated metal complexes ${ }^{1} \mathrm{H}$ NMR spectra were run. The ${ }^{1} \mathrm{H}$ NMR spectrum of CIP-o-phdn, in DMSO-d $\mathrm{D}_{6}$ (Table 4) showed the characteristic singlet at $\delta: 11 \mathrm{ppm}$ to the proton of carboxylic $(\mathrm{COOH})$. The resonance of the carboxylic proton $(\mathrm{COOH})$ is not detected in the spectra of the isolated solid complexes that suggest the coordination of CIP-o-phdn through its carboxylato oxygen atoms [28-30, 51]. Also, the ${ }^{1} \mathrm{H}$ NMR spectra for complexes exhibit new peaks in the range 4.10-5.13 ppm, due to the presence of water molecules in the complexes. On comparing main peaks of CIP-o-phdn with its complexes, it is observed that all the peaks of the free ligand are present in the spectra of the complexes with chemical shift upon binding of CIP-o-phdn to the metal ion [52].

Table 4. ${ }^{1} \mathrm{H}$ NMR values (ppm) and tentative assignments for (A) CIP-o-phdn; (B) [Cr(CIP-ophdn $\left.)\left(\mathrm{H}_{2} \mathrm{O}\right)_{2}\right]\left(\mathrm{CH}_{3} \mathrm{COO}\right)_{3} \cdot 10 \mathrm{H}_{2} \mathrm{O}$, (C) $\left[\mathrm{Mn}(\mathrm{CIP}-\mathrm{o}-\mathrm{phdn})\left(\mathrm{H}_{2} \mathrm{O}\right)_{2}\right] \mathrm{SO}_{4} \cdot 10 \mathrm{H}_{2} \mathrm{O}, \quad$ (D) $\quad[\mathrm{Fe}(\mathrm{CIP}-\mathrm{O}-$ phdn $\left.)\left(\mathrm{H}_{2} \mathrm{O}\right)_{2}\right]\left(\mathrm{NO}_{3}\right)_{3} .8 \mathrm{H}_{2} \mathrm{O}$ and (E) $\left[\mathrm{Co}(\mathrm{CIP}-\mathrm{o}-\mathrm{phdn})\left(\mathrm{H}_{2} \mathrm{O}\right)_{2}\right] \mathrm{Cl}_{2} .7 \mathrm{H}_{2} \mathrm{O}$.

\begin{tabular}{|c|c|c|c|c|c|}
\hline $\mathrm{A}$ & $\mathrm{B}$ & $\mathrm{C}$ & $\mathrm{D}$ & $\mathrm{E}$ & Assignments \\
\hline $1.21-1.34$ & $1.19-1.30$ & $0.82-1.62$ & 1.23 & $1.05-1.29$ & $\begin{array}{c}\delta \mathrm{H}_{1}-\mathrm{CH}_{2} \text { and }-\mathrm{CH} \\
\text { cyclopropane }\end{array}$ \\
\hline 2.09 & 2.09 & 2.09 & 2.09 & $2.08-2.26$ & $\delta \mathrm{H},-\mathrm{NH} ;$ piperazine \\
\hline 2.49 & 2.50 & 2.51 & 2.50 & $2.49-2.73$ & $\delta \mathrm{H}^{+}{ }^{-} \mathrm{NH}_{2}$ \\
\hline $3.32-3.86$ & $3.01-3.83$ & 3.44 & 3.33 & $3.33-3.77$ & $\delta \mathrm{H}_{2}-\mathrm{CH}_{2}$ aliphatic \\
- & 4.40 & 5.13 & 4.10 & 4.10 & $\delta \mathrm{H} \mathrm{H}_{2} \mathrm{O}$ \\
\hline $7.60-9.11$ & $7.57-8.67$ & $7.69-8.69$ & $7.88-8.30$ & $7.85-8.65$ & $\delta \mathrm{H},-\mathrm{CH}$ aromatic \\
\hline 11 & - & - & - & - & $\delta \mathrm{H},-\mathrm{COOH}$ \\
\hline
\end{tabular}

\section{Thermal studies}

Thermogravimetric (TGA) and differential thermogravimetric (DTG) analyses for CIP-o-phdn and their isolated solid complexes were carried out to get information about the thermal stability of these new complexes and to suggest a general Scheme for thermal decomposition as well as to ascertain the nature of associated water molecules. In the present investigation, heating rates were suitably controlled at $10{ }^{\circ} \mathrm{C} \mathrm{min}{ }^{-1}$ under nitrogen atmosphere and the weight loss is measured from the room temperature to $800{ }^{\circ} \mathrm{C}$. Figure 2 represent the TGA and DTG curves and Table 5 gives the maximum temperature values for decomposition along with the corresponding weight loss values for each step of the decomposition reaction. These data support the proposed complexes chemical formulae. CIP-o-phdn is thermally stable at room temperature and the decomposition started at $35{ }^{\circ} \mathrm{C}$ and finished at $715{ }^{\circ} \mathrm{C}$ with one stage at three maxima 200,311 and $630{ }^{\circ} \mathrm{C}$ and is accompanied by a weight loss of $99.82 \%$.

The thermal decompostion of $\left[\mathrm{Cr}(\mathrm{CIP}-\mathrm{o}-\mathrm{phdn})\left(\mathrm{H}_{2} \mathrm{O}\right)_{2}\right]\left(\mathrm{CH}_{3} \mathrm{COO}\right)_{3} \cdot 10 \mathrm{H}_{2} \mathrm{O}$ complex proceeds with two main degradation steps. The first stage of decomposition occurs at a temperature maximum of $60{ }^{\circ} \mathrm{C}$. The found weight loss associated with step is $15.19 \%$ and may be attributed to the loss of the ten water molecules which is in good agreement with the calculated values of $15.27 \%$. Loss of water crystallization at a relatively low temperature may indicate weak $\mathrm{H}$ bonding involving the $\mathrm{H}_{2} \mathrm{O}$ molecule and the complex. The second stage of decomposition occurs at three maxima 323,400 and $650{ }^{\circ} \mathrm{C}$ with intermediate formation of very unstable products which were not identified $[25,53,54]$ and the weight loss found at this stage equals $76.34 \%$ corresponds to loss $20 \mathrm{C}_{2} \mathrm{H}_{2}+3.5 \mathrm{~N}_{2}+\mathrm{NO}+2 \mathrm{HF}+4 \mathrm{CO}+5.5 \mathrm{H}_{2} \mathrm{O}$. For $\mathrm{Mn}(\mathrm{II})$ complex the thermal decomposition exhibits two main degradation steps. The first step of decomposition occurs from 25 to $282{ }^{\circ} \mathrm{C}$ is accompanied by a weight loss of $16.28 \%$ in agreement with the theoretical values $16.35 \%$ for the loss of ten uncoordinated water molecules (water of 
crystalization). The second step of decompostion occurs at four maxima 282, 332, 400 and 600 ${ }^{\circ} \mathrm{C}$ with a weight loss of $68.68 \%$ this associated with the loss of ciprofloxacin Schiff base forming manganize sulphate as a final product (Table 5). The thermal degradation for the [Fe(CIP-o-phdn) $\left.\left(\mathrm{H}_{2} \mathrm{O}\right)_{2}\right]\left(\mathrm{NO}_{3}\right)_{3} \cdot 8 \mathrm{H}_{2} \mathrm{O}$ exhibits two degradation steps. The first step of decomposition occurs in the range $25-175{ }^{\circ} \mathrm{C}$, with one maximum temperature at $75{ }^{\circ} \mathrm{C}$, is accompanied by a weight loss of $12.34 \%$ corresponding exactly to the loss of eight water molecules. The second step of degradation occurs at three maxima at 231,356 and $438{ }^{\circ} \mathrm{C}$ and is accompanied by a weight loss of $80.46 \%$, corresponding to the loss of $19 \mathrm{C}_{2} \mathrm{H}_{2}+10 \mathrm{NO}+2 \mathrm{HF}+0.5 \mathrm{~N}_{2}+0.5 \mathrm{H}_{2}+2 \mathrm{CO}+1.5 \mathrm{H}_{2} \mathrm{O}$. The actual weight loss from these two steps is $92.80 \%$, close to the calculated value $93.09 \%$. The $\left[\mathrm{Co}(\mathrm{CIP}-\mathrm{o}-\mathrm{phdn})\left(\mathrm{H}_{2} \mathrm{O}\right)_{2}\right] \mathrm{Cl}_{2} \cdot 7 \mathrm{H}_{2} \mathrm{O}$ complex decomposes in two steps within the temperature range $25-900{ }^{\circ} \mathrm{C}$ with total mass loss $93.00 \%$ leaving $\mathrm{CoO}$ as residue. The proposed structure formula on the basis of the results discussed in our paper located as follows (Scheme 1).

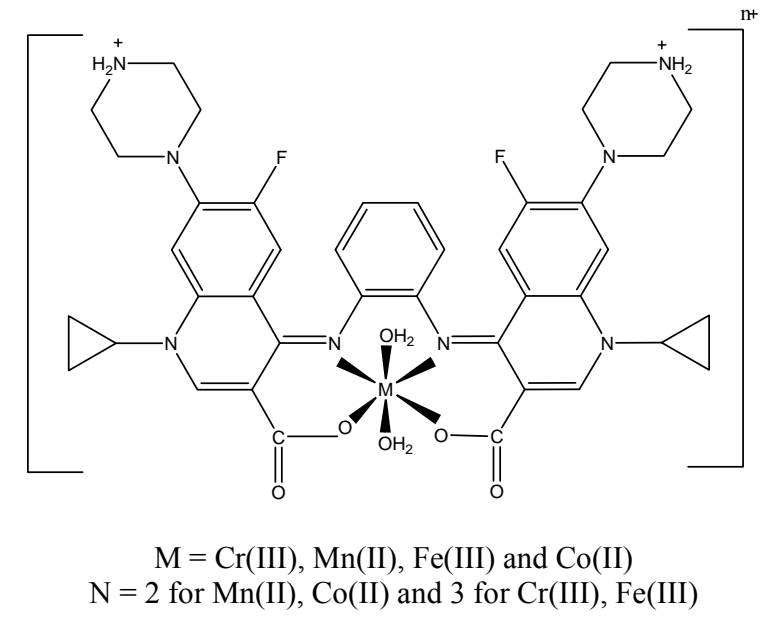

Scheme 1. The coordination mode of M with CIP-o-phdn. 

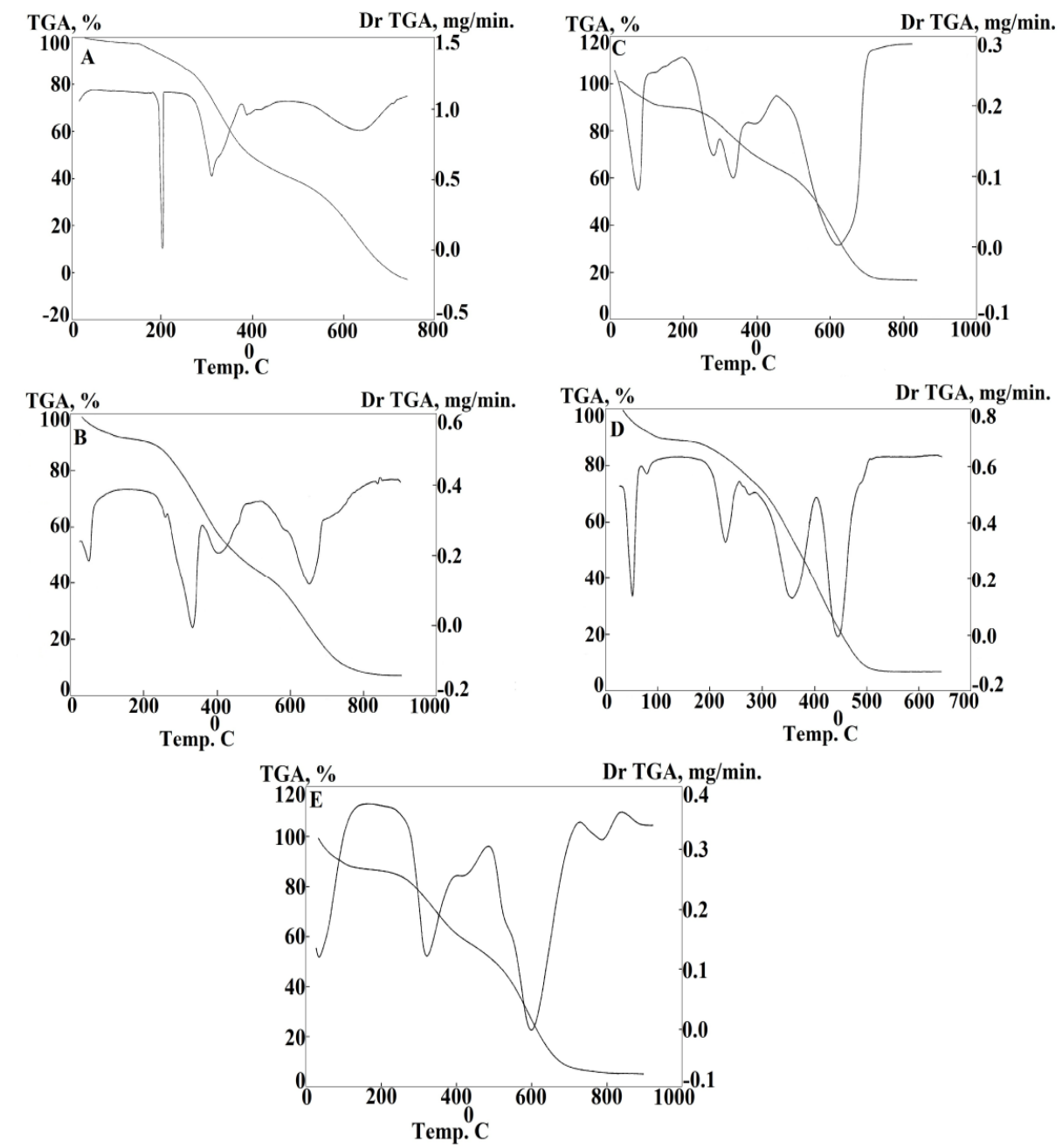

Figure 2. TGA and DTG diagrams for (A) CIP-o-phdn; (B) [Cr(CIP-o-phdn $\left.)\left(\mathrm{H}_{2} \mathrm{O}\right)_{2}\right]$ $\left(\mathrm{CH}_{3} \mathrm{COO}\right)_{3} \cdot 10 \mathrm{H}_{2} \mathrm{O},(\mathrm{C})\left[\mathrm{Mn}(\mathrm{CIP}-\mathrm{o}-\mathrm{phdn})\left(\mathrm{H}_{2} \mathrm{O}\right)_{2}\right] \mathrm{SO}_{4} \cdot 10 \mathrm{H}_{2} \mathrm{O}, \quad$ (D) $\quad[\mathrm{Fe}(\mathrm{CIP}-\mathrm{o}-\mathrm{phdn})$ $\left.\left(\mathrm{H}_{2} \mathrm{O}\right)_{2}\right]\left(\mathrm{NO}_{3}\right)_{3} .8 \mathrm{H}_{2} \mathrm{O}$ and (E) $\left[\mathrm{Co}(\mathrm{CIP}-\mathrm{o}-\mathrm{phdn})\left(\mathrm{H}_{2} \mathrm{O}\right)_{2}\right] \mathrm{Cl}_{2} .7 \mathrm{H}_{2} \mathrm{O}$.

Mass spectra

The idea of mass spectrometer builds up on the separation of fragments ions dependent to the variation of these ions with the ratio of mass to charge $(\mathrm{m} / \mathrm{z})$ [55]. Mass spectrum of the synthesized CIP-o-phdn was in a good agreement with the suggested structure (Scheme 2). CIPo-phdn showed molecular ion peak $\left(\mathrm{M}^{+}\right)$at $\mathrm{m} / \mathrm{z}=806.2(68.91 \%)$, and $\mathrm{M}^{+2}$ at $\mathrm{m} / \mathrm{z}=808(2.1 \%)$. The molecular ion peak [a] gave fragment which refer to base peak [b] at $\mathrm{m} / \mathrm{z}=604.20(100 \%)$. The molecular ion peak [a] losses $\mathrm{C}_{8} \mathrm{H}_{20} \mathrm{~N}_{4} \mathrm{Cl}_{2}$ to give fragment [c] at $\mathrm{m} / \mathrm{z}=564.20(48.74 \%)$ and it losses $\mathrm{C}_{6} \mathrm{H}_{10}$ to give fragment [d] at $\mathrm{m} / \mathrm{z}=723.20(57.14 \%)$. It loses $\mathrm{C}_{9} \mathrm{H}_{20} \mathrm{~N}_{4} \mathrm{O}_{2} \mathrm{Cl}_{2}$ to give [e] at $\mathrm{m} / \mathrm{z}=520.20(46.22 \%)$. The molecular ion peak [a] gave fragment [f] at $\mathrm{m} / \mathrm{z}=515.20$ 
Synthesis, characterization and antibacterial activity of some new transition metal complexes 269

(48.74\%) and also $[\mathrm{g}$ ] at $\mathrm{m} / \mathrm{z}=435.20(70.59 \%)$. The mass spectrum of $\mathrm{Co}$ (II) complex displayed molecular peak at 1024.9 which refer to M.Wt. of the complex with the abundance $10.10 \%$. For the other three complexes $\mathrm{Cr}(\mathrm{III}), \mathrm{Mn}$ (II) and $\mathrm{Fe}(\mathrm{III})$ with the calculated molecular weights 1179,1101 and 1155.8, respectively, according to the qualitative and thermogravimetric analyses, the molecular peaks are found outside the scale of the instrument.

Table 5. The maximum temperature $\mathrm{T}_{\max }\left({ }^{\circ} \mathrm{C}\right)$ and weight loss values of the decomposition stages for CIPo-phdn, $\mathrm{Cr}(\mathrm{III}), \mathrm{Mn}(\mathrm{II}), \mathrm{Fe}(\mathrm{III})$ and $\mathrm{Co}(\mathrm{II})$.

\begin{tabular}{|c|c|c|c|c|c|}
\hline \multirow[t]{2}{*}{ Compounds } & \multirow[t]{2}{*}{$\begin{array}{l}\text { Decompo- } \\
\text { sition }\end{array}$} & \multirow[t]{2}{*}{$\mathrm{T}_{\max }\left({ }^{\circ} \mathrm{C}\right)$} & \multicolumn{2}{|c|}{$\begin{array}{c}\text { Weight loss } \\
(\%)\end{array}$} & \multirow[t]{2}{*}{ Lost species } \\
\hline & & & Calc. & Found & \\
\hline $\begin{array}{c}\text { (CIP-o-phdn) } \\
\left.\mathrm{C}_{40} \mathrm{H}_{42} \mathrm{~N}_{8} \mathrm{O}_{4} \mathrm{~F}_{2} \mathrm{Cl}_{2}\right)\end{array}$ & $\begin{array}{l}\text { First step } \\
\text { Total loss } \\
\text { Residue }\end{array}$ & $200,311,630$ & $\begin{array}{l}100 \\
100\end{array}$ & $\begin{array}{l}99.82 \\
99.82\end{array}$ & $18 \mathrm{C}_{2} \mathrm{H}_{2}+4 \mathrm{CO}+2 \mathrm{HCl}+2 \mathrm{HF}+\mathrm{H}_{2}+4 \mathrm{~N}_{2}$ \\
\hline $\begin{array}{c}{[\mathrm{Cr}(\mathrm{CIP}-\mathrm{O}-} \\
\left.\text { phdn })\left(\mathrm{H}_{2} \mathrm{O}\right)_{2}\right]\left(\mathrm{CH}_{3} \mathrm{CO}\right. \\
\mathrm{O})_{3} .10 \mathrm{H}_{2} \mathrm{O} \\
\left.\mathrm{C}_{46} \mathrm{H}_{73} \mathrm{~N}_{8} \mathrm{O}_{22} \mathrm{~F}_{2} \mathrm{Cr}\right)\end{array}$ & $\begin{array}{l}\text { First step } \\
\text { Second step } \\
\text { Total loss } \\
\text { Residue }\end{array}$ & $\begin{array}{c}60 \\
323,400,650\end{array}$ & $\begin{array}{l}15.27 \\
76.25 \\
91.52 \\
8.48\end{array}$ & $\begin{array}{c}15.19 \\
76.34 \\
91.53 \\
8.47 \\
\end{array}$ & $\begin{array}{c}10 \mathrm{H}_{2} \mathrm{O} \\
20 \mathrm{C}_{2} \mathrm{H}_{2}+3.5 \mathrm{~N}_{2}+\mathrm{NO}+2 \mathrm{HF}+4 \mathrm{CO}+5.5 \mathrm{H}_{2} \mathrm{O} \\
\mathrm{CrO}_{1.5}+2 \mathrm{C}\end{array}$ \\
\hline $\begin{array}{c}{[\mathrm{Mn}(\mathrm{CIP}-\mathrm{o}-} \\
\left.\text { phdn })\left(\mathrm{H}_{2} \mathrm{O}\right)_{2}\right] \mathrm{SO}_{4} \\
10 \mathrm{H}_{2} \mathrm{O} \\
\left.\mathrm{C}_{40} \mathrm{H}_{64} \mathrm{~N}_{8} \mathrm{O}_{20} \mathrm{~F}_{2} \mathrm{SMn}\right)\end{array}$ & $\begin{array}{l}\text { First step } \\
\text { Second step } \\
\text { Total loss } \\
\text { Residue }\end{array}$ & \begin{tabular}{|c|}
64, \\
$282,332,400$ \\
600
\end{tabular} & $\begin{array}{c}16.35 \\
68.85 \\
85.20 \\
14.8\end{array}$ & $\begin{array}{l}16.28 \\
68.68 \\
84.96 \\
15.04\end{array}$ & $\begin{array}{c}10 \mathrm{H}_{2} \mathrm{O} \\
19 \mathrm{C}_{2} \mathrm{H}_{2}+3 \mathrm{NO}+\mathrm{CO}+2 \mathrm{HF}+2 \mathrm{H}_{2} \mathrm{O}+2.5 \mathrm{~N}_{2} \\
\mathrm{MnSO}_{4}+\mathrm{C}\end{array}$ \\
\hline $\begin{array}{c}{[\mathrm{Fe}(\mathrm{CIP}-\mathrm{O}-} \\
\left.\text { phdn })\left(\mathrm{H}_{2} \mathrm{O}\right)_{2}\right]\left(\mathrm{NO}_{3}\right)_{3} . \\
8 \mathrm{H}_{2} \mathrm{O} \\
\left.\mathrm{C}_{40} \mathrm{H}_{60} \mathrm{~N}_{11} \mathrm{O}_{23} \mathrm{~F}_{2} \mathrm{Fe}\right) \\
\end{array}$ & $\begin{array}{l}\text { First step } \\
\text { Second step } \\
\text { Total loss } \\
\text { Residue } \\
\end{array}$ & $\begin{array}{c}75 \\
231,356,438\end{array}$ & $\begin{array}{c}12,45 \\
80.64 \\
93.09 \\
6.91 \\
\end{array}$ & $\begin{array}{c}12.34 \\
80.46 \\
92.80 \\
7.20 \\
\end{array}$ & $\begin{array}{c}8 \mathrm{H}_{2} \mathrm{O} \\
19 \mathrm{C}_{2} \mathrm{H}_{2}+10 \mathrm{NO}+2 \mathrm{HF}+0.5 \mathrm{~N}_{2}+0.5 \mathrm{H}_{2}+2 \mathrm{CO}+ \\
1.5 \mathrm{H}_{2} \mathrm{O} \\
\mathrm{FeO}_{1.5} \\
\end{array}$ \\
\hline $\begin{array}{c}{[\mathrm{Co}(\mathrm{CIP}-\mathrm{O}-} \\
\left.\text { phdn })\left(\mathrm{H}_{2} \mathrm{O}\right)_{2}\right] \mathrm{Cl}_{2} \cdot 7 \mathrm{H}_{2} \mathrm{O} \\
\left(\mathrm{C}_{40} \mathrm{H}_{58} \mathrm{~N}_{8} \mathrm{O}_{13} \mathrm{~F}_{2} \mathrm{Cl}_{2} \mathrm{Co}\right)\end{array}$ & $\begin{array}{l}\text { First step } \\
\text { Second step } \\
\text { Total loss } \\
\text { Residue } \\
\end{array}$ & $\begin{array}{c}55 \\
314,586,759\end{array}$ & $\begin{array}{c}12.28 \\
80.42 \\
92.70 \\
7.30 \\
\end{array}$ & $\begin{array}{c}12.30 \\
80.70 \\
93.00 \\
7.00\end{array}$ & $\begin{array}{c}7 \mathrm{H}_{2} \mathrm{O} \\
20 \mathrm{C}_{2} \mathrm{H}_{2}+5 \mathrm{NO}+2 \mathrm{HF}+2 \mathrm{HCl}+1.5 \mathrm{~N}_{2} \\
\mathrm{CoO}\end{array}$ \\
\hline
\end{tabular}




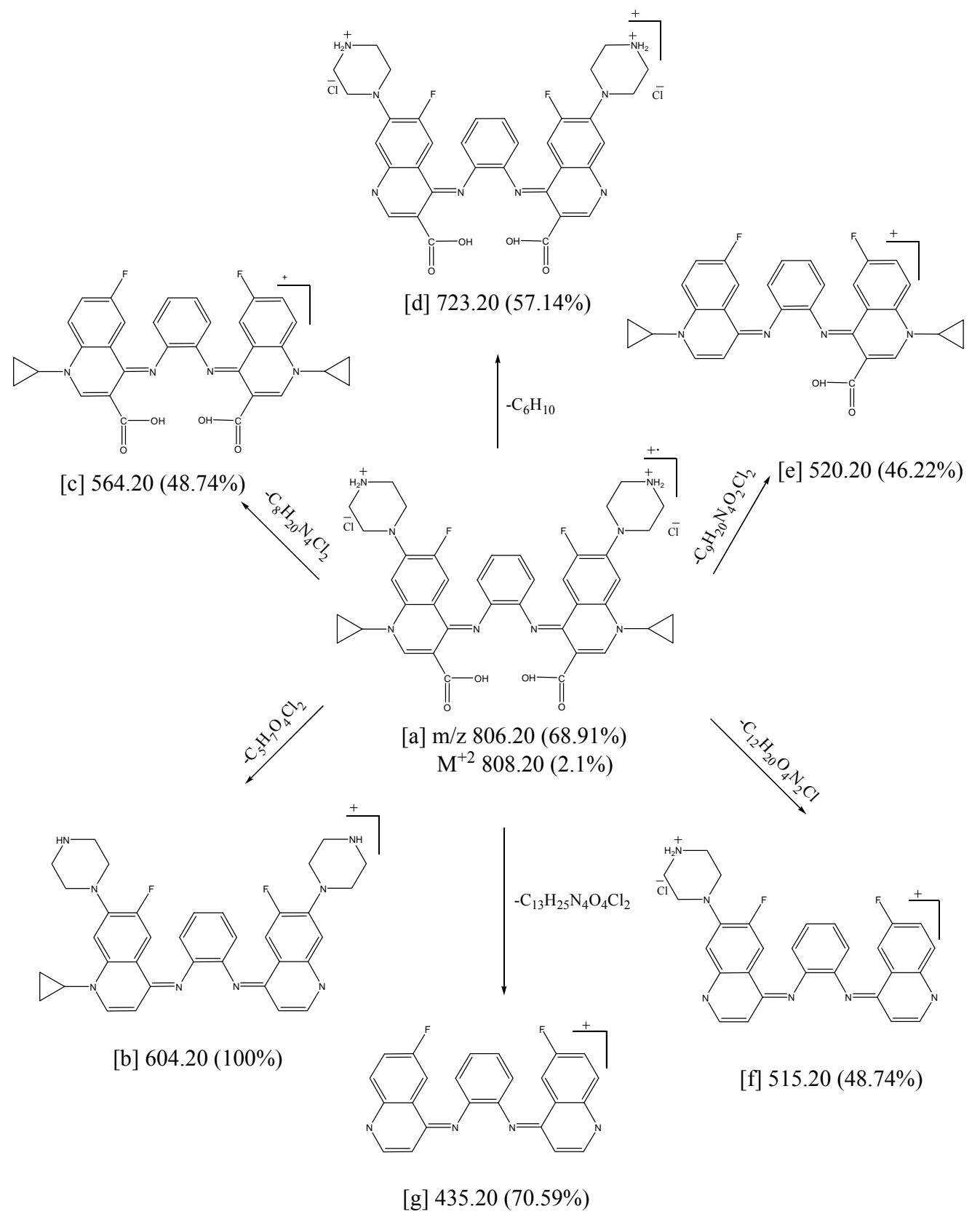

Scheme 2. Fragmentation pattern of CIP-o-phdn.

Bull. Chem. Soc. Ethiop. 2015, 29(2) 


\section{Biological activity}

The susceptibility of certain strains of bacterium, such as Staphylococcus aureus, Bacillus subtilis, Escherichia coli and Pseudomonas aeruginosa and antifungal screening was studied against two species Candida albicans and Aspergillus fumigates towards CIP-o-phdn, metal salts and its complexes was judged by measuring size of the inhibition diameter (Table 6 and Figure 3). As assessed by color, the complexes remain intact during biological testing. A comparative study of ligand and their metal complexes showed that the metal complexes exhibit higher antibacterial activity for Gram-positive and Gram-negative. Fe(III) is very highly significant for Escherichia coli and Pseudomonas aeruginosa and highly significant for Bacillus subtilis but $\mathrm{Mn}$ (II) showed moderated antibacterial activity for Escherichia coli, Pseudomonas aeruginosa and Bacillus subtilis and highly significant for Staphylococcus aureus, and no antifungal activity observed for ligand and their metal complexes (Table 6). The results are promising compared with the previous studies [51, 53, 56, 57]. Such increased activity of metal chelate can be explained on the basis of the oxidation state of the metal ion, overtone concept and chelation theory. According to the overtone concept of cell permeability, the lipid membrane that surrounds the cell favors the passage of only lipid-soluble materials in which liposolubility is an important factor that controls the antimicrobial activity. On chelation the polarity of the metal ion will be reduced to a greater extent due to overlap of ligand orbital and partial sharing of the positive charge of the metal ion with donor groups. Further it increases the delocalization of $\pi$-electrons over the whole chelate ring and enhances the lipophilicity of the complexes [51]. This increased lipophilicity enhances the penetration of complexes into the lipid membranes and blocks the metal binding sites in enzymes of microorganisms. These complexes also disturb the respiration process of the cell and thus block the synthesis of proteins, which restricts further growth of the microorganisms. Finaly, the data indicated that CIP-o-phdn exhibits higher antibacterial activity compared with free ciprofloxacin [53].

Table 6. The inhibition diameter zone values $(\mathrm{mm})$ for (CIP-o-phdn) and its metal complexes.

\begin{tabular}{|c|c|c|c|c|c|c|c|}
\hline \multirow{3}{*}{\multicolumn{2}{|c|}{ Tested compounds }} & \multicolumn{6}{|c|}{ Microbial species } \\
\hline & & \multicolumn{4}{|c|}{ Bacteria } & \multicolumn{2}{|c|}{ Fungi } \\
\hline & & E. coli & P. aeruginosa & B. subtilis & S. aureus & C. albicans & A. fumigatus \\
\hline \multicolumn{2}{|l|}{ CIP } & $27 \pm 0.35$ & $23 \pm 0.11$ & $32 \pm 0.22$ & $26 \pm 0.40$ & \begin{tabular}{|l|}
0 \\
\end{tabular} & 0 \\
\hline \multicolumn{2}{|l|}{ CIP-o-phdn } & $30 \pm 0.33$ & $25 \pm 0.11$ & $36 \pm 0.22$ & $29 \pm 0.90$ & 0 & 0 \\
\hline \multicolumn{2}{|c|}{$\begin{array}{l}{\left[\mathrm{Cr}(\mathrm{CIP}-\mathrm{o}-\mathrm{phdn})\left(\mathrm{H}_{2} \mathrm{O}\right)_{2}\right]\left(\mathrm{CH}_{3} \mathrm{COO}\right)_{3}} \\
.10 \mathrm{H}_{2} \mathrm{O}\end{array}$} & $40^{+1} \pm 0.22$ & $44^{+3} \pm 0.02$ & $46^{+1} \pm 0.44$ & $48^{+2} \pm 0.06$ & 0 & 0 \\
\hline \multicolumn{2}{|c|}{$\left[\mathrm{Mn}(\mathrm{CIP}-\mathrm{o}-\mathrm{phdn})\left(\mathrm{H}_{2} \mathrm{O}\right)_{2}\right] \mathrm{SO}_{4} .10 \mathrm{H}_{2} \mathrm{O}$} & $41^{+1} \pm 0.11$ & $35^{+1} \pm 0.03$ & $45^{+1} \pm 0.30$ & $50^{+2} \pm 0.88$ & 0 & 0 \\
\hline \multicolumn{2}{|c|}{$\left[\mathrm{Fe}(\mathrm{CIP}-\mathrm{o}-\mathrm{phdn})\left(\mathrm{H}_{2} \mathrm{O}\right)_{2}\right]\left(\mathrm{NO}_{3}\right)_{3} \cdot 8 \mathrm{H}_{2} \mathrm{O}$} & $50^{+3} \pm 0.22$ & $45^{+3} \pm 0.04$ & $52^{+2} \pm 0.20$ & $44^{+1} \pm 0.33$ & 0 & 0 \\
\hline \multicolumn{2}{|c|}{$\left[\mathrm{Co}(\mathrm{CIP}-\mathrm{o}-\mathrm{phdn})\left(\mathrm{H}_{2} \mathrm{O}\right)_{2}\right] \mathrm{Cl}_{2} \cdot 7 \mathrm{H}_{2} \mathrm{O}$} & $39^{+1} \pm 0.15$ & $43^{+3} \pm 0.05$ & $50^{+2} \pm 0.13$ & $50^{+2} \pm 0.11$ & 0 & 0 \\
\hline \multicolumn{2}{|c|}{$\mathrm{Cr}\left(\mathrm{OCOCH}_{3}\right)_{3}$} & 0 & 0 & 0 & 0 & 0 & 0 \\
\hline \multicolumn{2}{|c|}{$\mathrm{MnSO}_{4} \cdot 6 \mathrm{H}_{2} \mathrm{O}$} & 0 & 0 & 0 & 0 & 0 & 0 \\
\hline \multicolumn{2}{|c|}{$\mathrm{Fe}\left(\mathrm{NO}_{3}\right)_{3} .9 \mathrm{H}_{2} \mathrm{O}$} & $10 \pm 0.33$ & $12 \pm 0.11$ & 0 & 0 & 0 & 0 \\
\hline \multicolumn{2}{|c|}{$\mathrm{CoCl}_{2} \cdot 6 \mathrm{H}_{2} \mathrm{O}$} & 0 & 0 & 0 & 0 & 0 & 0 \\
\hline \multicolumn{2}{|c|}{ Control (DMF) } & 0 & 0 & 0 & 0 & 0 & 0 \\
\hline \multicolumn{2}{|c|}{ o-Phenylenediamine } & $15 \pm 0.33$ & 0 & 0 & 0 & 0 & 0 \\
\hline \multirow[t]{3}{*}{ Standard } & Ampicilin & 0 & 0 & $28 \pm 0.40$ & 0 & 0 & 0 \\
\hline & Amoxycilin & 0 & 0 & $22 \pm 0.11$ & $18 \pm 1.73$ & 0 & 0 \\
\hline & Cefaloxin & $24 \pm 0.34$ & 0 & $27 \pm 1.15$ & $16 \pm 0.52$ & 0 & 0 \\
\hline
\end{tabular}

Statistical significance $\mathrm{P}^{\mathrm{NS}} \mathrm{P}$ not significant, $\mathrm{P}>0.05 ; \mathrm{P}^{+1} \mathrm{P}$ significant, $\mathrm{P}<0.05 ; \mathrm{P}^{+2} \mathrm{P}$ highly significant, $\mathrm{P}<$ $0.01 ; \mathrm{P}^{+3} \mathrm{P}$ very highly significant, $\mathrm{P}<0.001$; student's $t$-test (paired). 

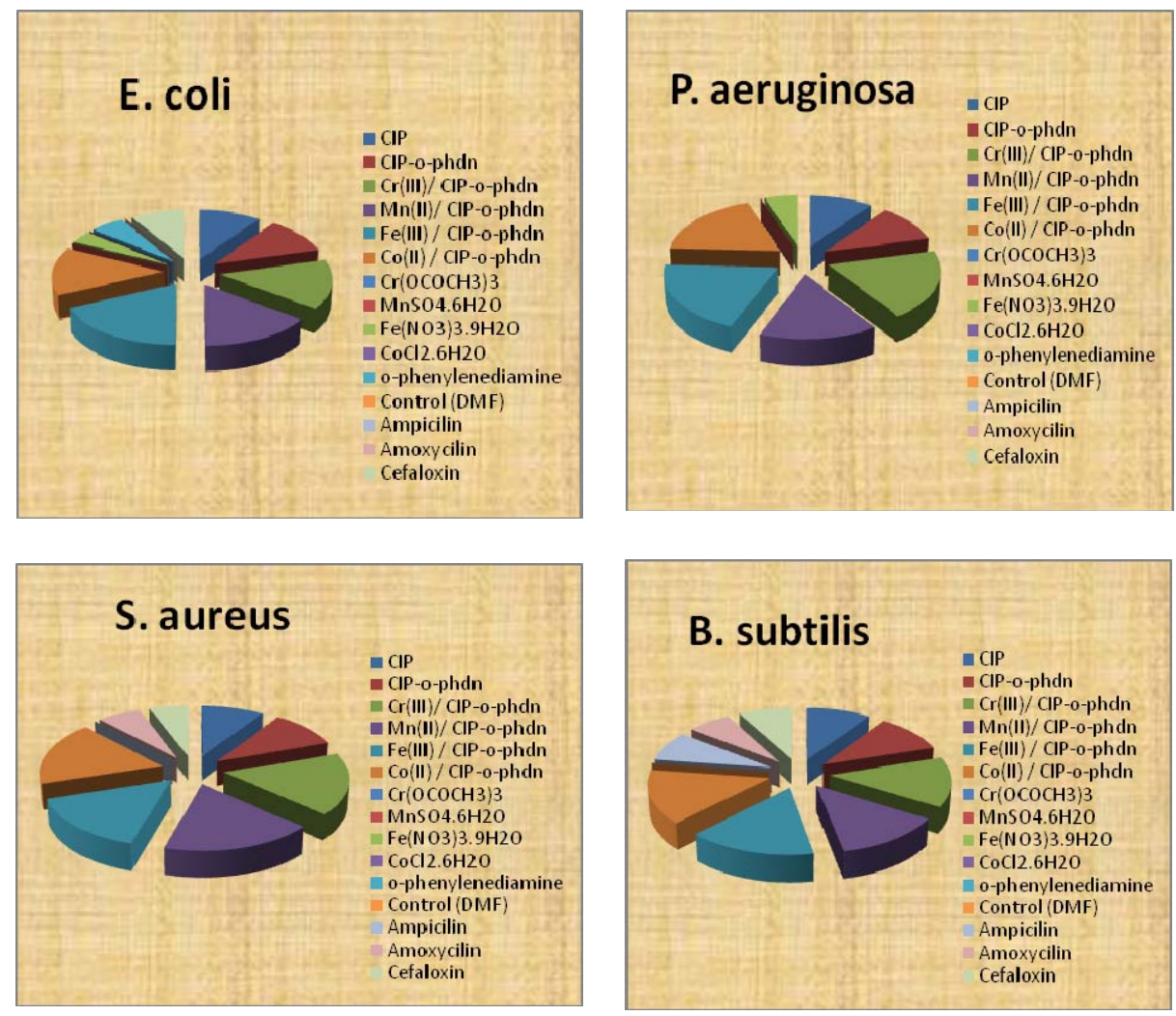

Figure 3.Statistical representation for biological activity of CIP-o-phdn and its metal complexes.

\section{CONCLUSION}

To summarize the new CIP-o-phdn tetradentate ligand (N,N'-o-phenylene bis 1-cyclopropyl-6fluoro-4-oxo-7-(piperazin-1-yl)-quinoline-3-carboxylic acid) has been synthesized and their coordination chemistry with $\mathrm{Cr}(\mathrm{III}), \mathrm{Mn}(\mathrm{II}), \mathrm{Fe}(\mathrm{III})$ and $\mathrm{Co}(\mathrm{II})$ has been studied. The four new complexes were characterized with physicochemical and spectroscopic methods. In all these complexes, CIP-o-phdn is on deprotonated mode and acts as tetradentate ligand bound to the metal ion through two oxygen atoms of carboxylate groups and two nitrogen atoms of azomethine groups. Each metal is six coordinate and the geometry described as distorted octahedral. The antibacterial activity of CIP-o-phdn is higher than ciprofloxacin alone.

\section{REFERENCES}

1. Dhar, D.N.; Taploo, C.L. J. Sci. Ind. Res. 1982, 41, 501.

2. Przybylski, P.; Huczynski, A.; Pyta, K.; Brzezinski, B.; Bartlf. Curr. Org. Chem. 2009, 13, 124.

3. Shaw, A.Y.; Chang, C.Y.; Hsu, M.Y.; Lu, P.J.; Yang, C.N.; Chen, H.L. Eur. J. Med. Chem. 2010, 45, 2860. 
Synthesis, characterization and antibacterial activity of some new transition metal complexes 273

4. Bringmann, G.; Dreyer, M.; Faber, J.H.; Dalsgaard P.W.; Staerk, D.; Jaroszewski, J.W. J. Nat. Prod. 2004, 67, 743.

5. De Souza, A.O.; Galetti, F.C.S.; Silva, C.L.; Bicalho, B.; Parma, M.M.; Fonseca, S.F. Quim. Nova. 2007, 30, 1563.

6. Guo, Z.; Xing, R.; Liu, S.; Zhong, Z.; Ji, X.; Wang, L. Carbohydr. Res. 2007, 10, 1329.

7. Khalil, S.M.E. Chem. Pap. 2000, 54, 12.

8. Hamilton, D.E.; Drago, R.S.; Zombeck, A. J. Am. Chem. Soc. 1987, 109, 374.

9. Chen, D.; Martel, A.E. J. Inorg. Chem. 1987, 26, 1026.

10. Nishinaga, A.; Yamada, T.; Fujisawa, H.; Ishizaki, K. J. Mol. Catal. 1988, 48, 249.

11. Xi, Z.; Liu, W.; Cao, G.; Du, W.; Huang, J.; Cai, K.; Guo, H. Cuihua. Xuobao. 1986, 7, 357.

12. Chakraborty, H.; Paul, N.; Rahman, M.L. Trans. Met. Chem. 1994, 19, 524.

13. Zhao, Y.D.; Pang, D.W.; Zong, Z.; Cheng, J.K.; Luo, Z.F.; Feng, C.J.; Shen, H.Y.; Zhung, X.C. Huaxue. Xuebao. 1988, 56, 178.

14. Sreekala, R.; Yusuff, K.K.; Mohammed, K.K. Catal. Pap. 1994, 507.

15. Ramesh, R.; Sugantyhy, P.K.; Natarajan, K. Synth. React. Inorg. Met.-Org. Chem. 1996, 26, 47.

16. Ohashi, Y. Bull. Chem. Soc. Jpn. 1997, 70, 1319.

17. Teleb, S.M.; Sadeek, S.A.; Nour, E.M. Spectrosc. Lett. 1993, 26, 169.

18. Nour, E.M.; Al-kority, A.M.; Sadeek, S.A.; Teleb, S.M. Synth. React. Inorg. Met.-Org. Chem. 1993, 23, 39.

19. Vogel, A.I. "Qualitative Inorganic Analysis”, 6th ed., Wiley: New York; 1987.

20. Beecher, D.J.; Wong, A.C. Appl. Environ. Microbial. 1994, 60, 1646.

21. Fallik, E.; Klein, J.D.; Grinberg, S.; Lomaniec, E.; Lurie, S.; Lalazar, A. J. Econ. Entomol. 1993, 77, 985.

22. Geary, W.J. Coord. Chem. Rev. 1971, 7, 81.

23. Chandra, S.; Kumar U. J. Saudi. Chem. Soc. 2004, 8, 77.

24. Keypour, H.; Shayesteh, M.; Sharifi-Rad, A.; Saleh Zadeh, S.; Khavasi, H.; Valencia, L. Organomet. Chem. 2008, 693, 3179.

25. Nakamoto, K. Infrared and Raman Spectra of Inorganic and Coordination Compounds, 4th ed., Wiley: New York; 1986; p 230.

26. Sadeek, S.A.; Teleb, S.M.; Refat, M.S.; Elmosallamy, M.A.F. J. Coord. Chem. 2005, 58, 1077.

27. Silverstein, R.M.; Bassler, G.C.; Morril, T.C. Spectroscopic Identification of Organic Compounds, 5th ed., Wiley: New York; 1991.

28. Turel, I.; Bukovec, P.; Quirós, M. Int. J. Pharm. 1997, 152, 59.

29. Sadeek, S.A.; Refat, M.S.; Hashem, H.A. J. Coord. Chem. 2006, 59, 759.

30. Sadeek, S.A.; EL-Shwiniy, W.H. J. Mol. Struct. 2010, 977, 243.

31. Sadeek, S.A.; EL-Shwiniy, W.H. J. Mol. Struct. 2010, 981, 130.

32. Gao, F.; Yang; P.; Xie; J.; Wang, H. J. Inorg. Biochem. 1995, 60, 61.

33. Sadeek, S.A.; EL-Shwiniy, W.H.; Zordok, W.A.; EL-Didamony, A.M. Spectrochim. Acta Part $A$ 2011, 78, 854.

34. Sadeek, S.A.; El-Attar, M.S.; Abd El-Hamid, S.M. J. Mol. Struct. 2013, 1051, 30.

35. Sadeek, S.A.; El-Attar, M.S.; Abd El-Hamid, S.M. Synth. React. Inorg. Met.-Org. NanoMetal Chem. 2015, 45, 1412.

36. Refat, M.S. Spectrochim. Acta 2007, 68, 1393.

37. Kessissoglou, D.P.; Manoussakis, G.E.; Hatzidimitriou, A.G.; Kanatzidis, M.G. Inorg. Chem. 1987, 26, 1395.

38. Davies, J.A.; Eagle, C.T.; Pinkerton, A.A.; Syed, R. Acta Cryst. 1987, 43, 1547.

39. Gregg, M.R.; Powell, J.; Sawyer, J.F. Acta Cryst. 1988, 44, 43.

40. Robertson, G.B; Tucker, P.A. Acta Cryst. 1983, 39, 858. 
41. Bryndza, H.E.; Calabrese, J.C.; Marsi, M.; Roe, D.C.; Tam, W.; Bercaw, J.E. J. Am. Chem. Soc. 1986, 108, 4805.

42. Manoussakis, G.; Bolos, C.; Ekateriniadou, L.; Sarris, C. Eur. J. Med. Chem. 1987, 22, 421.

43. Kortsaris, A.E.; Kyriakidis, D.A. Microbiologica 1988, 11, 347.

44. Nakamoto, K. Infrared and Raman Spectra of Inorganic and Coordination Compounds, Wiley: New York; 1963; p 232.

45. Deacon, G.B.; Phillips, R. Coord. Chem. Rev. 1980, 33, 227.

46. Nakamoto, K.; McCarthy, P.J.; FuJiwara, S.; Shimura, Y.; Fujita, J.; Hare, C.R.; Saito, Y. Spectroscopy and Structure of Metal Chelate Compounds, John Wiley and Sons, Inc.: New York; 1968.

47. Cotton, F.A.; Wilkinson, G.; Murillo, C.A.; Bochmann, M. Advanced Inorganic Chemistry, 6th ed., Wiley: New York; 1999.

48. Dubey, R.K.; Dubey, U.K.; Mishra, C.M. Indian J. Chem. A 2008, 47, 1208.

49. Lever, A.B.P. Coord. Chem. Rev. 1968, 3, 119.

50. Mondal, N.; Dey, D.K.; Mitra, S.; Abdul Malik, K.M. Polyhedron 2000, 19, 2707.

51. Muhammad, I.; Javed, I.; Shahid, I.; Nazia, I. Turk. J. Biol. 2007, 31, 67.

52. Skauge, T.; Turel, I.; Sletten, E. Inorg. Chem. Acta 2002, 339, 239.

53. Sadeek, S.A.; EL-Shwiniy, W.H.; Zordok, W.A.; EL-Didamony, A.M. Spectrochim. Acta (A) 2011, 78, 854 .

54. Brzyska, W.; Hakim, M. Polish J. Chem. 1992, 66, 413.

55. Sanmartin, J.; Novio, F.; Garcia-Deibe, A.M.; Fondo, M.; Ocampo, N.; Bermejo, M.R. Polyhedron 2006, 25, 1714.

56. Hughes, M.N. The Inorganic Chemistry of Biological Processes, 2nd ed., Wiley Interscience: New York; 1981.

57. Rossmore, H.W.; Block, S.S. (Eds.) Disinfection, Sterilization and Preservation, 4th ed., Lea and Febinger: Philadelphia; 1991; p 290. 